\title{
Isolation and characterization of Lactobacillus brevis C23 with ability to secrete antimicrobial substance for the inhibition of a foodborne pathogen Listeria monocytogenes ATCC 7644
}

\author{
Dharni Kuhan Sreedharan', Sahar Abbasiliasi², Paramasivam Murugan ${ }^{1}$, Zhang Jin Ng1, \\ Arbakariya Bin Ariff ${ }^{3,4}$ and Joo Shun Tan ${ }^{1 *}$
}

\author{
${ }^{1}$ School of Industrial Technology, Universiti Sains Malaysia, 11800 Gelugor, Pulau Pinang, Malaysia. \\ ${ }^{2}$ Halal Products Research Institute, Universiti Putra Malaysia, 43400 UPM Serdang, Selangor, Malaysia. \\ ${ }^{3}$ Department of Bioprocess Technology, Faculty of Biotechnology and Biomolecular Sciences, Universiti Putra Malaysia \\ UPM, Serdang 43400, Selangor, Malaysia \\ ${ }^{4}$ Bioprocessing and Biomanufacturing Research Centre, Faculty of Biotechnology and Biomolecular Sciences, Universiti \\ Putra Malaysia UPM, Serdang 43400, Selangor, Malaysia \\ Email: jooshun@usm.my
}

Received 9 September 2020; Received in revised form 14 October 2020; Accepted 23 February 2021

\begin{abstract}
Aims: This study aims to isolate lactic acid bacteria (LAB) from various food sources to obtain a potent strain against Listeria monocytogenes.

Methodology and results: A total of 68 LAB isolates were selected to evaluate their antimicrobial activity against $L$. monocytogenes, a foodborne pathogen and a causative agent of listeriosis. The selected isolate was identified and characterized. The isolate $\mathrm{C} 23$ from cabbage showed the highest antimicrobial activity against $L$. monocytogenes ATCC 7644 with inhibition ability of $73.94 \%$. The isolate was closely related to Lactobacillus brevis by $16 \mathrm{~S}$ rRNA sequencing and subsequently deposited in GenBank with an accession number of MN880215, named as L. brevis C23. The cell free supernatant (CFS) of L. brevis $\mathrm{C} 23$ had high tolerance in low $\mathrm{pH}$ and was able to withstand up to $60{ }^{\circ} \mathrm{C}$. The proteinaceous nature of the antimicrobial agent was also confirmed through the enzymatic test. The CFS was stable on different detergents as well as bile salts. Under transmission electron microscopy (TEM), the inhibitory effect of CFS against $L$. monocytogenes was proven by causing cell lysis.

Conclusion, significance and impact of study: Bacteriocin-like inhibitory substances (BLIS) of L. brevis C23 showed very promising potential in food industrial application.
\end{abstract}

Keywords: Lactic acid bacteria, Lactobacillus brevis, foodborne pathogen, Listeria monocytogenes, antimicrobial

\section{INTRODUCTION}

Foodborne diseases which have a massive impact on the economy worldwide is still not under control and its outbreaks can cause health and economic losses. For the past 20 years, there had been numerous outbreaks of foodborne diseases involving bacterial species of Salmonella spp., Listeria spp., and Escherichia coli (Amézquita and Brashears, 2002).

Listeria monocytogenes, a foodborne pathogen is a facultative anaerobic Gram-positive which is motile, nonspore forming, catalase positive and oxidase negative bacterium. Listeria monocytogenes are able to survive at various unfavourable environment, such as low $\mathrm{pH}$ and refrigeration temperature as well as tolerate high sodium chloride concentration (Složilová et al., 2014). Due to the highly adaptability nature, L. monocytogenes are found in raw meats and vegetables especially in ready to eat processed foods (Shamloo et al., 2019).

Chemical additives and preservatives are widely used in processed food to slow down pathogen growth, and extending its shelf life (Choi and Chin, 2003). Since $L$. monocytogenes are able to survive at most conditions, natural preservation such as curing and drying is futile. However, prolonged usage of chemical preservatives is dangerous for health. For instance, benzoates are known to worsen asthma, trigger allergies and cause urticarial while salicylates might cause child hyperactivity and other neurological disturbances (Abdulmumeen et al., 2012).

Biopreservation are in high demand due to its risk free to human health and environmental friendly (Ünlü et al., 2016). Bacteriocins are ribosomal synthesised protein produced by Gram-positive and some Gram-negative lactic acid bacteria (LAB). However, bacteriocin produced 
only by $L A B$ are used in food industry since it is Generally Regarded As Safe (GRAS status) (Nettles and Barefoot, 1993).

Antibacterial peptides or bacteriocins produced by many strains of LAB have been used as food preservatives for many years without any known adverse effects. Bacteriocins, especially those with broad antibacterial spectrum, are bactericidal against food spoilage and many pathogenic bacteria. In the commercialization of bacteriocins as food preservatives, there is a need to determine their antibacterial spectrum, biochemical characteristics, effectiveness and regulatory implications in the food system.

Bacteriocin exhibits a large antimicrobial spectrum which capable to be used in food packaging or as natural preservatives. Bacteriocin exert bactericidal effect by interrupting cell wall synthesis or by pore formation on target's plasma membrane (Güllüce et al., 2013). However, the use of the bacteriocin is very limited due to technological or legislation barriers, but intensive studies are carried out to diversify its use in the food industry. The aim of this study is to investigate the potential use of bacteriocin-like inhibitory substances (BLIS) from locally isolated $L A B$ strains against a foodborne pathogen $L$. monocytogenes. The cell-free supernatant (CFS) with the highest antimicrobial activity against $L$. monocytogenes ATCC 7644 was selected and characterized.

\section{MATERIALS AND METHODS}

\section{Isolation of BLIS producing strains}

A total of seven different food sources such as yoghurt, tofu, cabbage and guava were obtained from a Penang market, Malaysia; oil palm trunk sap was collected from I.K Panel (M) Sdn. Bhd. located at Nibong Tebal, Malaysia; homemade fermented rice and human breast's milk was obtained from a healthy mother in Penang, Malaysia. The samples were suspended into $0.85 \%(\mathrm{w} / \mathrm{v})$ $\mathrm{NaCl}$ (Fisher Scientific, New Hampshire, Unites States) and homogenized well. The sample was serially diluted to 10 -fold using $0.85 \%(\mathrm{w} / \mathrm{v})$ sodium chloride $(\mathrm{NaCl})$ and spread platted on de Man Rogosa Sharpe (MRS) agar (Merck, Darmstadt, Germany) and M17 agar (Merck, Darmstadt, Germany). The agar plates were incubated at $37{ }^{\circ} \mathrm{C}$ for $48 \mathrm{~h}$. Distinctive colonies were selected and streaked to obtain pure colonies. The pure isolates were cultured in MRS broth for $24 \mathrm{~h}$ at $37^{\circ} \mathrm{C}$ and kept at -80 ${ }^{\circ} \mathrm{C}$ in $30 \%(\mathrm{v} / \mathrm{v})$ glycerol for long term storage (St. Louis, Missouri, US)

\section{Screening of antimicrobial activity against $L$. monocytogenes ATCC 7644}

A total of 59 isolates as well as 9 strains from our stock culture were screened for antimicrobial activity. The isolates were cultured in MRS and M17 broth for $24 \mathrm{~h}$ at $37^{\circ} \mathrm{C}$. The cultures were centrifuged at $8000 \mathrm{~g}$ for $20 \mathrm{~min}$ at $4{ }^{\circ} \mathrm{C}$. Then, CFS was filter-sterilized using $0.22 \mu \mathrm{m}$ filter membrane (Minisart ${ }^{\circledR}$, Sartorius). Listeria monocytogenes
ATCC 7644 was used as an indicator strain in which the CFS was tested for its antimicrobial activity. Listeria monocytogenes ATCC 7644 was cultured in Brain Heart Infusion (BHI) broth (Merck, Darmstadt, Germany) for 24 $\mathrm{h}$ at $37^{\circ} \mathrm{C}$ and diluted to $0.02 \pm 0.005$ of optical density (OD) at $600 \mathrm{~nm}$ to give $10^{6} \mathrm{CFU}$. After that, broth microdilution method was carried out in 96-well plate as described by $\mathrm{Ng}$ et al. (2020). In this assay, $100 \mu \mathrm{L}$ of $L$. monocytogenes ATCC 7644 cell suspension was added with $100 \mu \mathrm{L}$ of CFS into the 96-well plate. For the negative control, the CFS was replaced with MRS broth, while for positive control streptomycin $(10 \mathrm{mg} / \mathrm{mL})$ was used (Santa Cruz Biotechnology, Dallas, United State). The 96 well-plate was incubated at $37{ }^{\circ} \mathrm{C}$ for $24 \mathrm{~h}$. Turbidity was measured at $596 \mathrm{~nm}$ and the percentage of growth inhibition of CFS against $L$. monocytogenes ATCC 7644 calculated using following equation:

$$
\text { Percentage of inhibition }(I), \%=\frac{O D \text { control }-O D \text { sample }}{O D \text { control }} \times 100
$$

Where, OD control represents the change in OD of growth control (L. monocytogenes ATCC 7644 mixed with MRS broth) and OD sample represents the change in the optical density of the sample ( $L$. monocytogenes ATCC 7644 mixed with CFS).

Identification of BLIS producing isolate by $16 \mathrm{~S}$ rRNA sequencing and phylogenetic tree analysis

The BLIS producing isolate which produced the highest percentages of inhibition against $L$. monocytogenes ATCC 7644 was analysed by $16 \mathrm{~S}$ rRNA sequencing. The universal primers of $785 \mathrm{~F}$ (5'GGATTAGATACCCTGGTA-3') and 907R (5'CCGTCAATTCMTTTRAGTTT-3') were used to purify and sequence the $P C R$ products. The initial denaturation temperature of the PCR was at $94{ }^{\circ} \mathrm{C}$ for $3 \mathrm{~min}$ then continued by 35 cycles of denaturation for $30 \mathrm{sec}$ at 94 ${ }^{\circ} \mathrm{C}$, followed by annealing for $30 \mathrm{sec}$ at $58{ }^{\circ} \mathrm{C}$ and extension for $30 \mathrm{sec}$ at $72{ }^{\circ} \mathrm{C}(\mathrm{Ng}$ et al., 2020). Multiple sequence alignment and the phylogenetic tree was conducted with MEGA $X$ version 10.1.6 and neighbour joining method was used to construct phylogenetic tree (Figure 1).

\section{Effect of physio-chemical factors on stability of CFS Heat stability of CFS}

Heat stability of CFS was tested by heating $10 \mathrm{~mL}$ of filtered sterilized CFS at $40^{\circ} \mathrm{C}, 50{ }^{\circ} \mathrm{C}, 60^{\circ} \mathrm{C}, 70{ }^{\circ} \mathrm{C}, 80$ ${ }^{\circ} \mathrm{C}, 90^{\circ} \mathrm{C}, 100^{\circ} \mathrm{C}$ for $2 \mathrm{~h}$. The CFS was then cooled down to room temperature $\left(25^{\circ} \mathrm{C}\right)$. The antimicrobial activity of the heat treated CFS were tested against the $L$. monocytogenes ATCC 7644 in a 96-well plate using broth microdilution method as mentioned above.

\section{pH stability of CFS}

The $\mathrm{pH}$ sensitivity of CFS was tested by adjusting the $\mathrm{pH}$ 


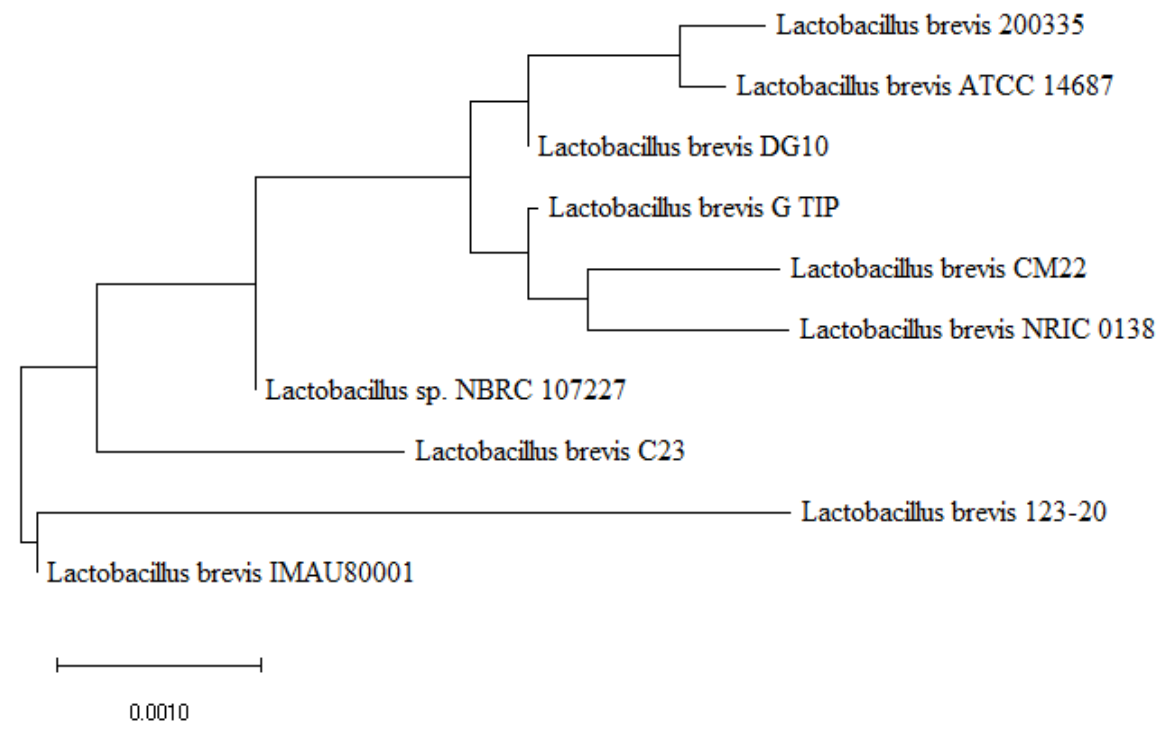

Figure 1: Neighbour-joining tree based on 16S rRNA sequencing showing the phylogenetic relationship between the isolated strain Lactobacillus brevis C23.

of CFS to 2, 3, 4, 5, 6, 7, 8, 9, and 10 using $1 \mathrm{~N}$ hydrochloric acid $(\mathrm{HCl})$ and $1 \mathrm{~N}$ sodium hydroxide $(\mathrm{NaOH})$. The $\mathrm{pH}$-adjusted CFS was incubated at $37^{\circ} \mathrm{C}$ for $2 \mathrm{~h}$. The antimicrobial activity of the $\mathrm{pH}$-adjusted CFS was tested against the L. monocytogenes ATCC 7644 in a 96well plate using broth microdilution method as mentioned above.

\section{Effect of enzymes on CFS}

The effect of different enzymes including a-amylase (TCI, Tokyo, Japan), catalase ( Nacalai Tesque, Kyoto, Japan), lipase (Himedia, Mumbai, India), papain, pepsin (Himedia, Mumbai, India), proteinase K (Merck, Darmstadt, Germany) and trypsin (Himedia, Mumbai, India) on CFS was tested at concentration of $0.1 \mathrm{mg} / \mathrm{mL}$ and $1 \mathrm{mg} / \mathrm{mL}$. A total of $1 \mathrm{~mL}$ of CFS were incubated in the presence of enzymes at $1: 1$ ratio and incubated for $2 \mathrm{~h}$ at $37^{\circ} \mathrm{C}$. The mixture was heated at $85^{\circ} \mathrm{C}$ for $10 \mathrm{~min}$ to inactivate the enzymes. The antimicrobial activity of the treated CFS was tested against L. monocytogenes ATCC 7644 using broth microdilution method as described above.

\section{Effect of detergent on CFS}

The effect of detergents on CFS activity was tested with urea (R\&M Chemicals, Essex, United Kingdom), sodium dodecyl sulfate (Sigma, St. Louis, Missouri, United States), NaCl (Fisher Scientific, New Hampshire, Unites States), ethylenediaminetetraacetic acid (EDTA) (Amresco, Solon, Ohio, United States), Tween 20, Tween 80 and Triton X-100 (Sigma, St. Louis, Missouri, United States). The detergents were added into the CFS at a final concentration of $10 \mathrm{mg} / \mathrm{mL}(\mathrm{w} / \mathrm{v})$. The CFS with the presence of detergent was incubated for $2 \mathrm{~h}$ at $37^{\circ} \mathrm{C}$. The antimicrobial activity of the treated CFS was tested against the L. monocytogenes ATCC 7644 using broth microdilution method.

\section{Fermentation of carbohydrate}

Sugar fermentation of selected isolate was analysed with API $50 \mathrm{CHL}$ system kit, following the procedures provided by the manufacturer (BioMérieux, Lyon, France). The colour changes were recorded at $24 \mathrm{~h}$ and $48 \mathrm{~h}$ (Abbasiliasi et al., 2012).

\section{Bile salt tolerance test}

Lactobacillus brevis C23 culture was cultured in MRS broth for $24 \mathrm{~h}$ at $37^{\circ} \mathrm{C}$. Bile salts (Oxoid, United Kingdom) were prepared at concentrations of $0.3 \%, 0.5 \%$ and $1 \%$ $(\mathrm{w} / \mathrm{v})$. One $\mathrm{mL}$ of overnight L. brevis C23 culture was inoculated into $10 \mathrm{~mL}$ of MRS broth in the presence of different concentrations of bile salts $(0.3 \%, 0.5 \%$ and $1 \%$ $(\mathrm{w} / \mathrm{v}))$ and incubated at $37^{\circ} \mathrm{C}$ for $5 \mathrm{~h}$. The growth of $L$. brevis $\mathrm{C} 23$ were measured spectrophotometrically at OD600 nm and defined in terms of the cell dry weight (DCW). The relationship between dry cell weight and OD600 was observed as $0.779 \mathrm{~g} \mathrm{DCW/L/OD600.}$

\section{Adsorption study}

The adsorption of BLIS on the producer cells was carried out according to the methods described by Yang et al. (1992). Lactobacillus brevis C23 culture was grown at 37 ${ }^{\circ} \mathrm{C}$ for $24 \mathrm{~h}$. The initial culture $\mathrm{pH}(\mathrm{pH} 5.76)$ was adjusted to $\mathrm{pH} 6.5$ and centrifuged at $8000 \mathrm{~g}$ for $20 \mathrm{~min}$ at $4{ }^{\circ} \mathrm{C}$. The supernatant was discarded, and the pellet was washed with sterile $0.1 \mathrm{M}$ phosphate buffer $(\mathrm{pH} 6.5)$. The 
cells were resuspended in $10 \mathrm{~mL}$ of sterile $100 \mathrm{mM} \mathrm{NaCl}$ (pH 2) (Fisher Scientific, New Hampshire, Unites States) and stirred for $1 \mathrm{~h}$ at $4^{\circ} \mathrm{C}$. The suspended cells with $\mathrm{NaCl}$ were centrifuged at $8000 \mathrm{~g}$ for $20 \mathrm{~min}$ at $4^{\circ} \mathrm{C}$ and filtered using $0.22 \mu \mathrm{m}$ filter membrane. The antimicrobial activity was tested against the L. monocytogenes ATCC 7644 in a 96-well plate using broth microdilution method.

\section{Effect of CFS on L. monocytogenes ATCC 7644 using} transmission electron microscope (TEM)

Listeria monocytogenes ATCC 7644 was cultured for $24 \mathrm{~h}$ at $37^{\circ} \mathrm{C}$. CFS was added into the culture and incubated for $24 \mathrm{~h}$ at $37^{\circ} \mathrm{C}$ for the test and MRS broth was replaced with CFS and used as negative control. After $24 \mathrm{~h}$, both cultures were centrifuged at $8000 \times g$ for $20 \mathrm{~min}$. The supernatants were discarded and the pellets from both cultures kept for TEM analysis. The pellets were fixed in $2.5 \%$ glutaraldehyde in $0.1 \mathrm{M}$ sodium cacodylate buffer for 4 to $6 \mathrm{~h}$. The samples were centrifuged, and the supernatants pipetted to remove the fixative. A few drops of horse serum were added to each of the pellets. The coagulated pellets were then diced into $1 \mathrm{~mm}^{3}$ pieces. Following three washings with sodium cacodylate buffer, the samples were post-fixed in $1 \%$ aqueous osmium tetroxide and dehydrated in ascending grades of acetone dilutions $(30 \%, 50 \%, 75 \%, 80 \%, 95 \%$ and $100 \%)$. Samples were then infiltrated overnight with a 50:50 mixture of resin and acetone. The following morning, samples were infiltrated with $100 \%$ resin and dropped into resin-filled, pre-labeled beam capsules and polymerized at $60^{\circ} \mathrm{C}$ for $16 \mathrm{~h}$. Ultrathin sections on copper grids were stained with uranyl acetate and lead citrate and examined by TEM (Abbasiliasi et al., 2017).

\section{Statistical analysis}

All of the data obtained were analysed using SPSS version 22.0 (IBM, New York, USA). One-way analysis of variance was carried out to study the significance difference between means. All the data obtained from duplicates were expressed as means value. The significance level was set at $\alpha=0.05$ and the data were analysed by Tukey's test.

\section{RESULTS}

\section{Isolation and screening of BLIS-producing LAB}

A total of 59 unidentified isolates were selected based on the morphologies of the colonies such as size, colour and shape (Table 1). Most of the colonies were small in size and circular in shape. The notable colours of the colonies were white while some were creamy. However, 3 of the colonies obtained from the oil palm trunk sap were yellowish in colour with a web-like pattern on the colony surface.

The 59 unknown isolates and 9 identified strains were tested for the antimicrobial activity by broth microdilution

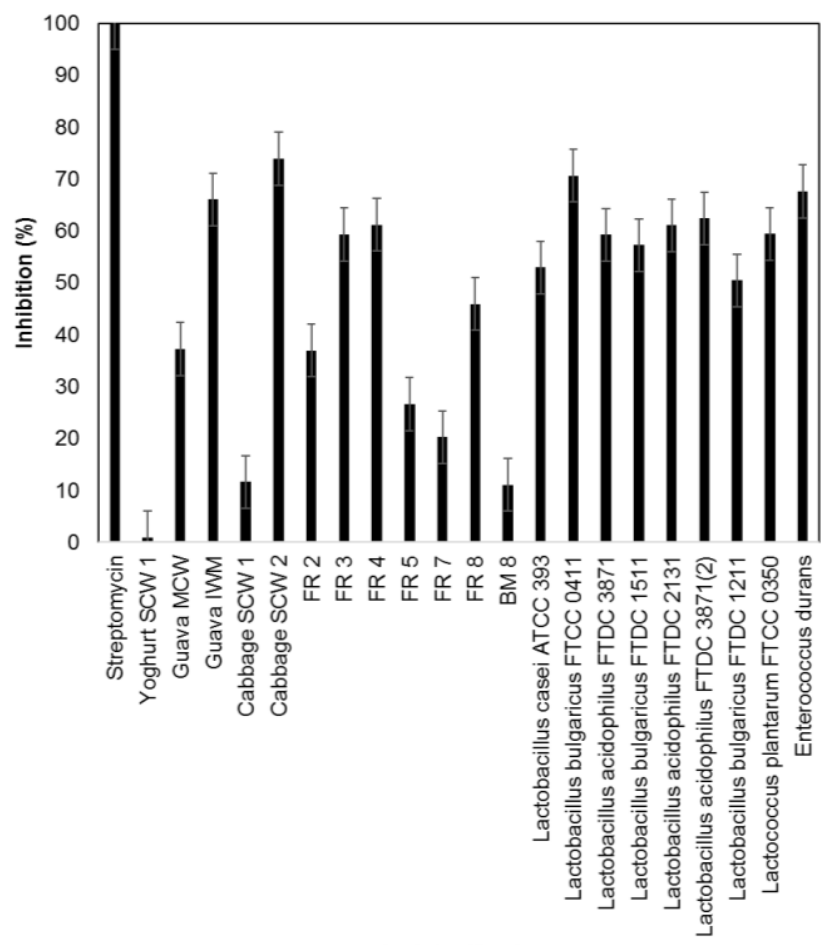

Isolates/Strain

Figure 2: Percentage of inhibition (\%) on $L$. monocytogenes ATCC 7644 by CFS from different LAB showing inhibitory effect. FR represents fermented oil palm sap; Streptomycin $(10 \mathrm{mg} / \mathrm{mL})$ acted as positive control. Results were expressed as mean and standard deviation, where tests were performed in triplicate.

method. Among the 59 different distinctive isolates, 12 isolates showed positive antimicrobial activity against of L. monocytogenes ATCC 7644 with four of it showed more than $50 \%$ inhibition (Figure 2). The highest growth of inhibition was at $74 \%$ from cabbage isolate (SCW 2) and the lowest growth of inhibition was at $0.90 \%$ from yoghurt (SCW 1). For identified strains, L. bulgaricus FTCC 0411 had the highest inhibition percentage of $70.94 \%$, while L. bulgaricus FTDC 1211 showed the lowest inhibition percentage of $50.45 \%$. The isolate from cabbage SCW2, which had the highest antimicrobial activity was selected for 16S rRNA sequencing identification.

Identification of selected isolates by 16S rRNA sequencing and phylogenetic analysis

The results from $16 \mathrm{~S}$ rRNA sequencing revealed that SCW 2 with the nucleotide sequences (1521 bp) showed $99.8 \%$ of pairwise similarities to $L$. brevis G TIP (MK530232.1). It was showed the isolate SCW 2 was closely related to $L$. brevis and named as $L$. brevis $C 23$. The 16S rRNA nucleotide sequence of $L$. brevis C23 was deposited in GenBank with the accession number of MN880215. 
Malays. J. Microbiol. Vol 17(3) 2021, pp. 266-276

DOI: http://dx.doi.org/10.21161/mjm.200996

Table 1: Isolation of LAB strains from different food sources on selective medium of MRS and M17 agar and their colony's morphologies.

\begin{tabular}{|c|c|c|c|}
\hline Isolates/strain & Sources & Agar plates & Colony's morphology \\
\hline SCW 1 & Yoghurt & MRS & Small, whitish, circular \\
\hline MCW 1 & & MRS & Medium size, whitish, circular \\
\hline SCW 2 & & M17 & Small, whitish, circular \\
\hline MCW 2 & & M17 & Medium size, whitish, circular \\
\hline SCW 1 & Tofu & M17 & Small, whitish, circular \\
\hline VSCW 1 & & M17 & Very small size, whitish, circular \\
\hline SCW 2 & & MRS & Small, whitish, circular \\
\hline VSCW 2 & & MRS & Very small size, whitish, circular \\
\hline MCW & Guava & MRS & Medium size, whitish, circular \\
\hline LCW & & MRS & Large, whitish, circular \\
\hline SCW & & M17 & Small, whitish, circular \\
\hline IWM & & MRS & Medium size, whitish, irregular \\
\hline SCW 1 & Cabbage & MRS & Small, whitish, circular \\
\hline SCW 2 & & M17 & Small, whitish, circular \\
\hline VSCW 1 & & MRS & Very small size, whitish, circular \\
\hline FR 1 & Fermented rice & MRS & Large, pale whitish, irregular \\
\hline FR 2 & & MRS & Medium size, creamy, circular \\
\hline FR 3 & & MRS & Small, creamy, oval \\
\hline FR 4 & & MRS & Small, whitish, circular \\
\hline FR 5 & & MRS & Small, whitish, oval \\
\hline FR 6 & & MRS & Medium size, creamy, circular \\
\hline FR 7 & & MRS & Small, whitish, circular \\
\hline FR 8 & & MRS & Small, whitish, oval \\
\hline FR 9 & & MRS & Medium size, whitish, circular \\
\hline FR 10 & & MRS & Small, whitish, star shape \\
\hline FR 11 & & MRS & Small, whitish, oval \\
\hline FR 12 & & MRS & Medium size, whitish, irregular shape \\
\hline FR 13 & & M17 & Very large, creamy, irregular shape \\
\hline FR 14 & & M17 & Medium size, creamy with white border, irregular shape \\
\hline FR 15 & & M17 & Very large, creamy, irregular shape \\
\hline FR 16 & & M17 & Medium shape, creamy, circular \\
\hline FR 17 & & M17 & Large, creamy, irregular shape \\
\hline FR 18 & & M17 & Very large, whitish, irregular shape \\
\hline MM 1 & Mother's milk & MRS & Small, whitish, circular \\
\hline MM 2 & & MRS & Small, whitish, circular \\
\hline MM 3 & & MRS & Medium shape, milky, irregular shape \\
\hline MM 4 & & MRS & Small, whitish, circular \\
\hline MM 5 & & MRS & Medium shape, creamy, circular \\
\hline MM 6 & & MRS & Medium shape, whitish, circular \\
\hline MM 7 & & MRS & Small, creamy, oval \\
\hline MM 8 & & MRS & Medium, creamy, irregular shape \\
\hline MM 9 & & MRS & Small, whitish, oval \\
\hline MM 10 & & MRS & Small, creamy, circular \\
\hline MM 11 & & MRS & Very small, creamy, oval \\
\hline MM 12 & & M17 & Very small, creamy, irregular shape \\
\hline MM 13 & & M17 & Small, whitish, circular \\
\hline MM 14 & & M17 & Small, creamy, oval \\
\hline MM 15 & & M17 & Small, creamy, oval \\
\hline MM 16 & & M17 & Small, whitish, circular \\
\hline MM 17 & & M17 & Very small, creamy, oval \\
\hline MM 18 & & M17 & Very small, creamy, circular \\
\hline MM 19 & & M17 & Very small, creamy, oval \\
\hline MM 20 & & M17 & Medium shape, creamy, circular \\
\hline $\begin{array}{l}\text { FOP } 1 \\
\text { FOP } 2\end{array}$ & Fermented oil palm sap & $\begin{array}{l}\text { M17 } \\
\text { M17 }\end{array}$ & $\begin{array}{l}\text { Very large, whitish, irregular } \\
\text { Medium shape, yellowish, circular }\end{array}$ \\
\hline
\end{tabular}

(Continued) 


\begin{tabular}{lll}
\hline FOP 3 & M17 & Very small, creamy, oval \\
FOP 4 & M17 & Medium shape, yellowish, circular \\
FOP 5 & M17 & Very large, creamy, irregular shape \\
FOP 6 & M17 & Medium shape, yellowish, circular \\
\hline
\end{tabular}

\section{Characterization of CFS from L. brevis C23}

\section{Heat stability of CFS}

Heat stability of CFS from L. brevis C23 was tested at 40 ${ }^{\circ} \mathrm{C}, 50{ }^{\circ} \mathrm{C}, 60{ }^{\circ} \mathrm{C}, 70{ }^{\circ} \mathrm{C}, 80^{\circ} \mathrm{C}, 90^{\circ} \mathrm{C}$ and $100{ }^{\circ} \mathrm{C}$ and results are as in Table 2 . The CFS of $L$. brevis C23 was stable up to $60{ }^{\circ} \mathrm{C}$. The growth inhibition of $L$. monocytogenes showed there is no significant difference $(p<0.05)$ between them at $40^{\circ} \mathrm{C}, 50^{\circ} \mathrm{C}$ and $60^{\circ} \mathrm{C}$. The CFS tested at temperature $40^{\circ} \mathrm{C}$ recorded the highest growth inhibition against $L$. monocytogenes ATCC 7644 at $85.37 \%$, followed by $50{ }^{\circ} \mathrm{C}(85.15 \%)$. When the temperature increased to $70{ }^{\circ} \mathrm{C}$, the growth of $L$. monocytogenes exhibited very low inhibition (6.83\%) which is lower as compared to $60{ }^{\circ} \mathrm{C}(82.67 \%)$. There was no growth inhibition of L. monocytogenes when temperatures increased to $80^{\circ} \mathrm{C}, 90^{\circ} \mathrm{C}$ and $100^{\circ} \mathrm{C}$.

\section{pH stability of CFS}

The $\mathrm{pH}$ stability test of CFS from L. brevis C23 from acidic to alkaline environment was conducted. From Table 2, the CFS favoured acidic condition as the highest growth inhibition of $87.02 \%, 81.77 \%$ and $86.13 \%$, against L. monocytogenes ATCC 7644 was obtained at $\mathrm{pH} 2,3$ and 4 , respectively. The results of growth inhibition of CFS against $L$. monocytogenes ATCC 7644 from $\mathrm{pH} 2$ to $\mathrm{pH} 4$ were markedly higher than $\mathrm{pH} 5$. The growth inhibition recorded at $\mathrm{pH} 5$ was $53.86 \%$, which is $33.15 \%$ lower as compared to $\mathrm{pH} 2$ to 4 . There was no growth inhibition when the $\mathrm{pH}$ increased from 6 to 10 .

\section{Effect of different enzymes on CFS stability}

Results from effect of different enzymes ( $\alpha$-amylase, catalase, lipase, papain, pepsin, proteinase $\mathrm{K}$ and trypsin) on CFS are as in Table 2. The growth inhibition of CFS against $L$. monocytogenes ATCC 7644 was relatively stable when treated with different enzymes at $0.1 \mathrm{mg} / \mathrm{mL}$. There is no significant difference for the growth inhibition by CFS treated with the enzymes at concentration of 0.1 $\mathrm{mg} / \mathrm{mL}$, but it was significantly higher as compared to the enzymes at $1 \mathrm{mg} / \mathrm{mL}(p<0.05)$. As for the CFS treated with enzymes at concentration of $1 \mathrm{mg} / \mathrm{mL}$, only the CFS treated with catalase, $\alpha$-amylase and pepsin showed positive inhibition against L. monocytogenes ATCC 7644. The highest growth inhibition against $L$. monocytogenes ATCC 7644 was $45.86 \%$ from catalase, followed by $\alpha$ amylase $(36.19 \%)$ and pepsin $(0.84 \%)$. There was no growth of inhibition when CFS treated with enzyme proteinase $\mathrm{K}$, trypsin, lipase and papain at $1 \mathrm{mg} / \mathrm{mL}$.
Table 2: The stability test of CFS at different temperature, $\mathrm{pH}$, enzymes and detergents against $L$. monocytogenes ATCC 7644.

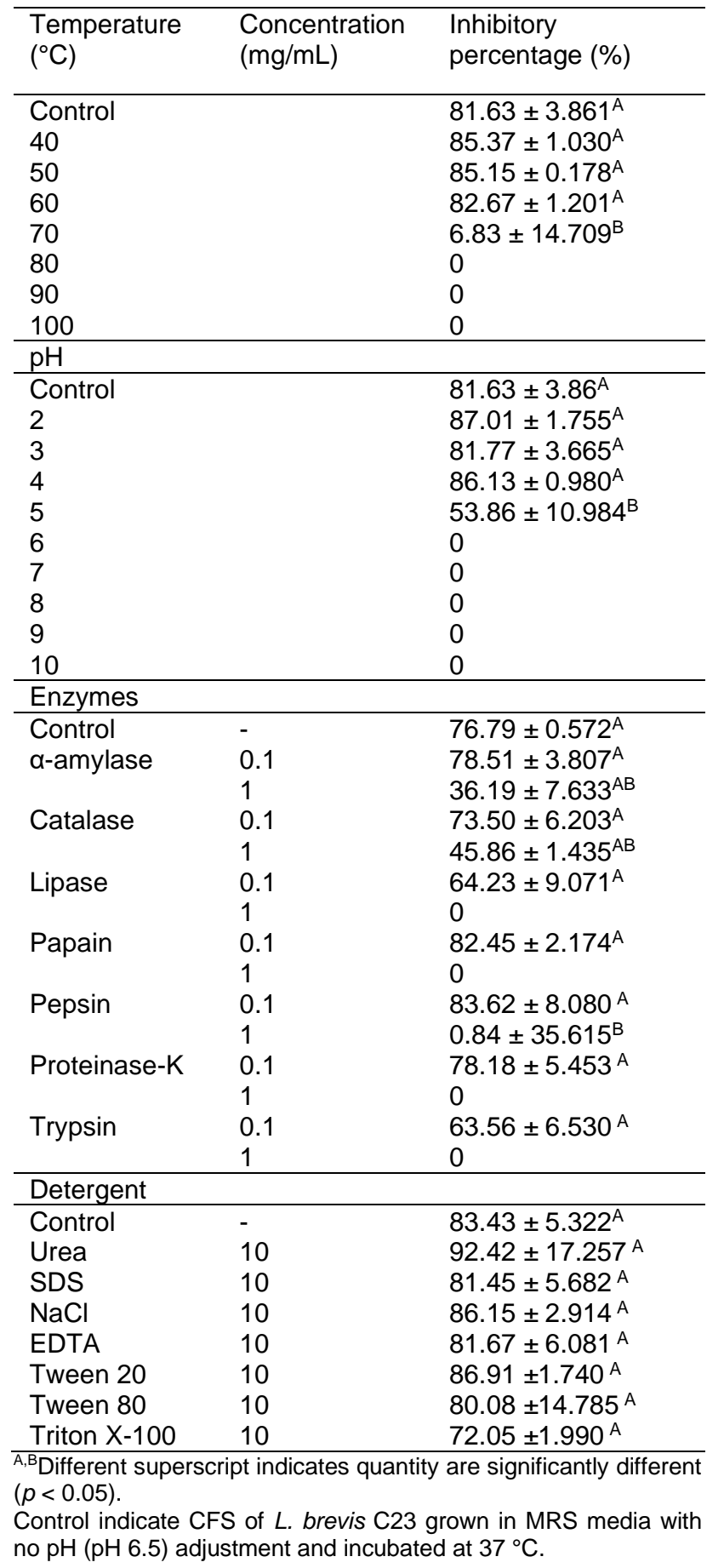




\section{Effect of detergent on CFS stability}

Different types of detergents with concentration of 10 $\mathrm{mg} / \mathrm{mL}$ were tested for the stability of CFS (Table 2). The growth inhibition of CFS against $L$. monocytogenes ATCC 7644 was relatively stable when treated with all types of detergent. There was no significant difference $(p<0.05)$ of the CFS when treated with the detergents. The highest growth inhibition of $L$. monocytogenes by the CFS was $92.42 \%$ which treated with urea. Tween 80 , Tween 20, $\mathrm{NaCl}$, EDTA and SDS showed $80.08 \%, 86.91 \%, 86.15 \%$, $81.67 \%$ and $81.45 \%$ of growth inhibition of $L$. monocytogenes, respectively. The growth inhibition of CFS tested with Triton X-100 was $72.05 \%$, which was the lowest among the other detergents.

\section{Fermentation of carbohydrate by L. brevis C23}

The carbohydrate metabolism reaction of isolate was analysed with API $50 \mathrm{CHL}$ system kit (BioMérieux, Lyon, France). The results for carbohydrate metabolism profile after $24 \mathrm{~h}$ and $48 \mathrm{~h}$ were as observed in Table 3 . Lactobacillus brevis C23 able to metabolize 4 different carbohydrates including D-ribose, D-xylose, D-fructose, D-maltose and partially metabolize potassium gluconate and potassium 5-ketogluconate at $24 \mathrm{~h}$. At $48 \mathrm{~h}$, L. brevis hydrolysed additional 4 carbohydrate and partially metabolized 1 carbohydrate, L-arabinose, D-glucose,
methyl-aD-glucopyranoside, D-melibiose and Nacetylglucosamine.

\section{Bile salt tolerance of $L$. brevis $\mathrm{C} 23$}

Tolerance of the isolates to bile salts was conducted with the culture of $L$. brevis $\mathrm{C} 23$ suspended in different concentrations of bile salts $(0 \%, 0.3 \%, 0.5 \%$, and $1.0 \%)$. Based on Figure 3, the L. brevis C23 culture without bile salts showed the highest cell dry weight $(0.716 \mathrm{mg})$, while culture with $0.5 \%$ bile salts had the lowest cell dry weight $(0.630 \mathrm{mg})$ after $5 \mathrm{~h}$ of incubation. On the other hand, the culture with $0.3 \%$ and $1 \%$ of bile salts gave a cell dry weight of $0.647 \mathrm{mg}$ and $0.641 \mathrm{mg}$, respectively. The difference of cell dry weight of $L$. brevis C23 culture with $1 \%$ of bile salts in comparison to the highest cell dry weight at $5^{\text {th }}$ hour was $0.075 \mathrm{mg}$.

\section{Adsorption study}

In Table 4, the CFS of L. brevis C23 was used as control and the growth inhibition of the CFS against $L$. monocytogenes ATCC 7644 was $94.36 \%$. No antimicrobial activity was detected after treatment of $L$. brevis $\mathrm{C} 23$ with $100 \mathrm{mM} \mathrm{NaCl}$ solution at $\mathrm{pH} 2$, in which the percentage of inhibition on L. monocytogenes ATCC 7644 by the $L$. brevis $\mathrm{C} 23$ cells (without $\mathrm{pH}$ adjusted) was $0.25 \%$ and $\mathrm{pH}$ adjusted L. brevis C23 cells $(\mathrm{pH} 6.5)$ was $0 \%$.

Table 3: Biochemical analysis of carbohydrate fermentation of $L$. brevis $\mathrm{C} 23$ using API $50 \mathrm{CH}$ system.

\begin{tabular}{|c|c|c|c|c|c|}
\hline Carbohydrate & $24 \mathrm{~h}$ & $48 \mathrm{~h}$ & Carbohydrate & $24 \mathrm{~h}$ & $48 \mathrm{~h}$ \\
\hline control & - & - & esculin/ ferric citrate & - & - \\
\hline glycerol & - & - & salicin & - & - \\
\hline erythritol & - & - & D-cellobiose & - & - \\
\hline D-arabinose & - & - & D-maltose & ++ & ++ \\
\hline L-arabinose & - & ++ & D-lactose(bovine) & - & - \\
\hline D-ribose & ++ & ++ & D-melibiose & - & ++ \\
\hline D-xylose & ++ & ++ & D-saccharose(sucrose) & - & - \\
\hline L-xylose & - & - & trehalose & - & - \\
\hline D-adonitol & - & - & inulin & - & - \\
\hline methyl-ßD-xylopyranoside & - & - & melezitose & - & - \\
\hline D-galactose & - & - & raffinose & - & - \\
\hline D-glucose & - & ++ & amidon & - & - \\
\hline D-fructose & ++ & ++ & glycogen & - & - \\
\hline D-mannose & - & - & xylitol & - & - \\
\hline L-sorbose & - & - & gentiobiose & - & - \\
\hline L-rhamnose & - & - & D-turanose & - & - \\
\hline dulcitol & - & - & D-lyxose & - & - \\
\hline inositol & - & - & D-tagatose & - & - \\
\hline D-mannitol & - & - & D-fucose & - & - \\
\hline D-sorbitol & - & - & L-fucose & - & - \\
\hline methyl-aD-mannopyranoside & - & - & D-arabitol & - & - \\
\hline methyl-aD-glucopyranoside & - & ++ & L-arabitol & - & - \\
\hline N-acetylglucosamine & - & + & potassium gluconate & + & + \\
\hline amygladin & - & - & potassium 2-ketogluconate & - & - \\
\hline arbutin & - & - & potassium 5-ketogluconate & + & + \\
\hline
\end{tabular}

Interpretation of L. brevis sugar utilisation in API $50 \mathrm{CH}$ system at 24 hours and 48 hours; ++ indicates utilisation of sugar (yellow); + indicates partial utilisation of sugar (green); - indicates no utilisation of sugar. 
Malays. J. Microbiol. Vol 17(3) 2021, pp. 266-276 DOI: http://dx.doi.org/10.21161/mjm.200996

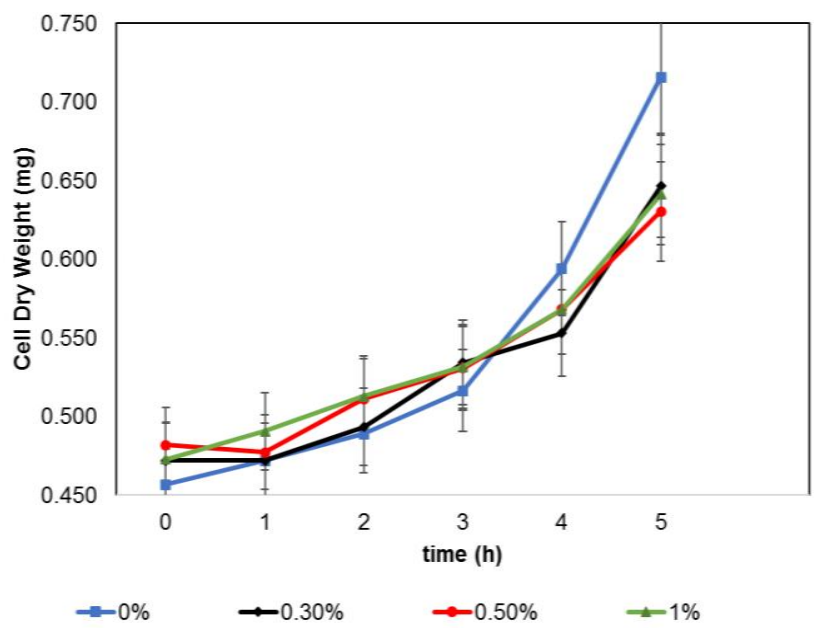

Figure 3: Tolerance of $L$. brevis $\mathrm{C} 23$ against different concentrations of bile salts. $0 \%$ represents the cell dry weight of $L$. brevis without bile salts; $0.3 \%$ represents the cell dry weight of $L$. brevis $C 23$ with addition of $0.3 \%$ of bile salts; $0.5 \%$ represents the cell dry weight of $L$. brevis with addition of $0.5 \%$ of bile salts; $1 \%$ represents the cell dry weight of $L$. brevis with addition of $1 \%$ of bile salts.

Table 4: Adsorption of the BLIS in CFS of L. brevis C23 towards the surface of the producer cells by inhibition determination against $L$. monocytogenes ATCC 7644 .

\begin{tabular}{lc}
\hline CFS & Inhibition percentage (\%) \\
\hline Control (CFS) $(\mathrm{pH} \mathrm{5.76)}$ & $94.36 \pm 2.42^{\mathrm{A}}$ \\
Cells I & $0.25 \pm 16.17^{\mathrm{B}}$ \\
Cells II & 0 \\
\hline
\end{tabular}

Control represents cell free supernatant (CFS).

Cells I represents CFS without $\mathrm{pH}$ adjustment before suspending in $\mathrm{NaCl}(\mathrm{pH} 2)$.

Cells II represents CFS with $\mathrm{pH}$ adjusted to $\mathrm{pH} 6.5$ before suspending in $\mathrm{NaCl}(\mathrm{pH} 2)$.

${ }^{*}$ Results are expressed as mean \pm standard deviation $(n=2)$. Different superscript indicates quantity are significantly different $(p<0.05)$.

\section{Evaluation of the effect of CFS on L. monocytogenes ATCC 7644 using TEM}

Listeria monocytogenes ATCC 7644 with and without treatment of CFS from $L$. brevis C23 was viewed under TEM to elucidate effect of CFS on bacterial cells. In Figure 4B, L. monocytogenes ATCC 7644 when treated with CFS was severely damaged. The cell wall and cytoplasm membrane breached, releasing the cytoplasmic content out of the cell which resulted in cell death. On the contrary, L. monocytogenes ATCC 7644 without treatment with CFS showed the cell retained in its rod shape (Figure 4A). A smooth surface of cell wall and cytoplasm membrane was observed by enveloping the cells. Cytoplasm content also remained intact within the cytoplasm membrane.
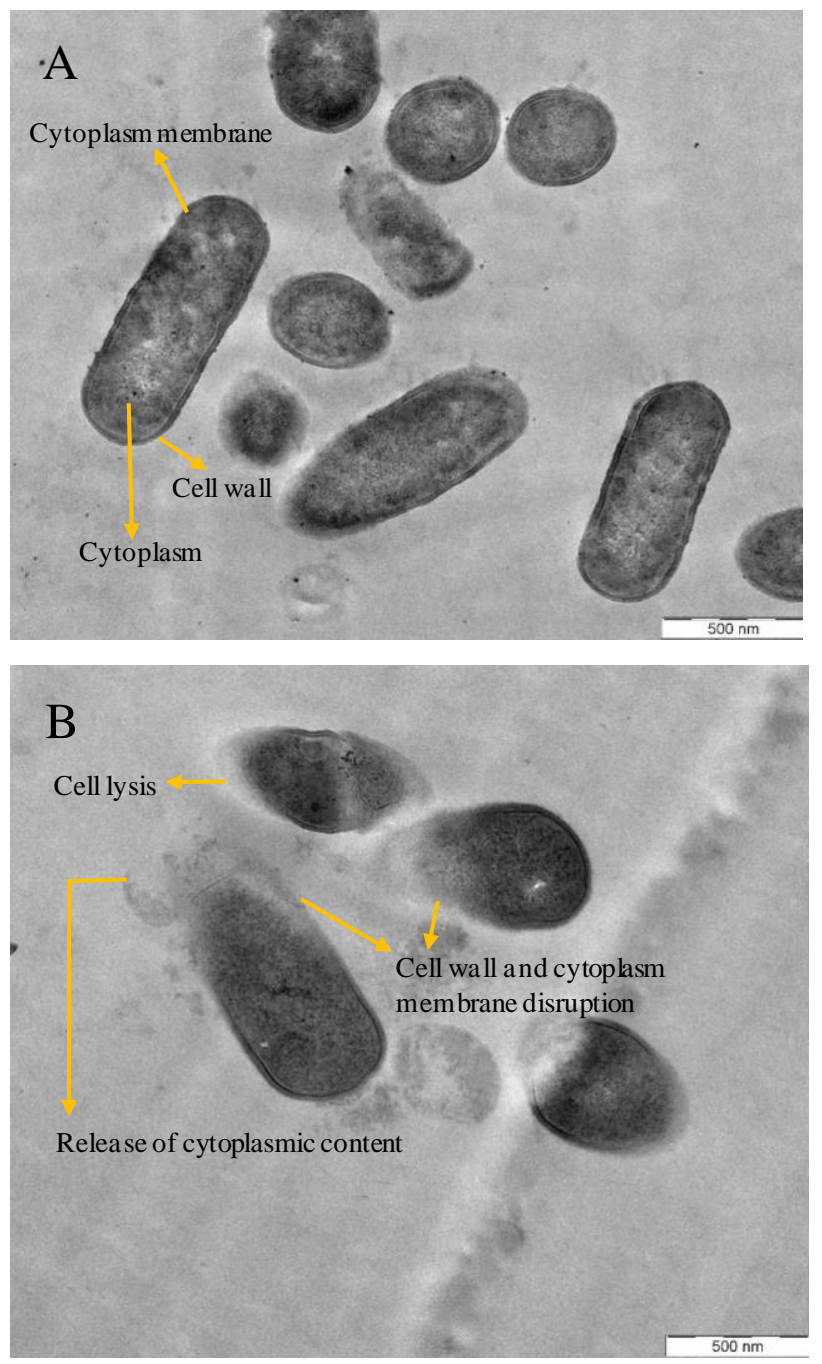

Figure 4: Morphology of L. monocytogenes ATCC 7644 under transmission electron microscope. $L$. monocytogenes without treatment $(\mathrm{A})$ and with treatment (B) of CFS from L. brevis C23.

\section{DISCUSSION}

In this study, the BLIS from L. brevis C23 showed high antimicrobial activity against $L$. monocytogenes ATCC 7644 , is similar to the previous report in which the $L$. brevis (MF179529) isolated from cow faecal sample also exhibited significant antilisterial activity (Riaz et al., 2019). The heat stability test showed that CFS of L. brevis C23 was sensitive to temperature beyond $60{ }^{\circ} \mathrm{C}$. This is in contrast to a previous study on heat stability of bacteriocin from $L$. brevis OG1 which exhibited maximum bacteriocin activity at $121{ }^{\circ} \mathrm{C}$ for 60 min (Ogunbanwo et al., 2003). It was reported bacteriocin produced by Lactobacillus species able to resist in high temperature (Yi et al., 2016). However, some bacteriocins produced by lactic acid 
bacteria are heat labile peptide. For instances, the bacteriocin from Streptococcus thermophilus 81 was stable until $50^{\circ} \mathrm{C}$ (Ivanova et al., 1998). Similar result was also observed in helveticin $\mathrm{J}$ produced by $L$. helveticus 1829 with heat stability until $50^{\circ} \mathrm{C}$ (Vaughan et al., 1992). The $\mathrm{pH}$ sensitivity test of the CFS of $L$. brevis C23 showed high antimicrobial activity and there was no significance difference $(p>0.05)$ among the $\mathrm{pH}$ from 2 to 4. The antimicrobial activity was stable even at $\mathrm{pH} 2$, in which this BLIS of $L$. brevis C23 can be widely applied in food preservation especially acidic food. However, the antimicrobial activity decreased from $\mathrm{pH} 5$ and there were no activities beyond $\mathrm{pH} 6$. A similar study on lactocin XN8-A produced by L. coryniformis XN8 displayed the highest antimicrobial activity from $\mathrm{pH} 4$ to $\mathrm{pH} 6$ and the activity decreased thereafter. This is due to protein denaturation at high $\mathrm{pH}$ level by strong intramolecular electrostatic interactions when the amino and carboxyl splits (Yi et al., 2016).

The enzyme sensitivity test of the CFS of $L$. brevis C23 showed that CFS was sensitive to proteolytic enzymes such as trypsin, pepsin, proteinase $\mathrm{K}$ and papain at $1 \mathrm{mg} / \mathrm{mL}$. There was no antimicrobial activity recorded when tested with these enzymes confirming the proteinaceous nature of BLIS from L. brevis C23. It is in agreement with the results of Avaiyarasi et al. (2016) who reported that antimicrobial activity of bacteriocin produced by Lactobacillus sakei GM3 was lost after the treatment of pepsin, trypsin and proteinase $\mathrm{K}$. As for treatment with catalase at 0.1 and $1 \mathrm{mg} / \mathrm{mL}$, the antimicrobial activity of CFS was not fully inhibited, confirming that the antimicrobial activity of CFS was not due to the presence of hydrogen peroxidase (Ogunbanwo et al., 2003). The antimicrobial activity of CFS was not fully inhibited when treated with $\alpha$-amylase at 0.1 and $1 \mathrm{mg} / \mathrm{mL}$ indicating that the bacteriocin is not glycosylated. A similar result was reported on antimicrobial activity of bacteriocin produced from Pediococcus acidilacti $\mathrm{HA}-6111-2$ and $P$. acidilacti HA-5692-3 after treating with catalase and $\alpha$-amylase. When the CFS was treated with lipase, there was no antimicrobial activity at $1 \mathrm{mg} / \mathrm{mL}$ suggesting that the bacteriocin is lipid moiety (Albano et al., 2007).

In the detergent stability test, CFS was relatively stable in all the detergents at $10 \mathrm{mg} / \mathrm{mL}$. The stability against surfactants and detergents favours a broad application of the bacteriocin because of its potential to retain its structure and function during different purification steps. Previous study showed that the plantaricin LPL-1 from $L$. plantarum LPL-1 had no difference in the antimicrobial activity when tested with EDTA, Tween 20, Tween 80, and urea, hence the BLIS is suitable to be used for emulsified food (Wang et al., 2018). Similar other study also reported that bacteriocin from $L$. plantarum bacST202Ch and $L$. plantarum bacST216Ch showed high resistance on the detergents (Todorov et al., 2010). There are many studies on the stability of bacteriocins on surfactants but mostly did not highlight the bactericidal effect of individual detergent. In the study of Millette et al. (2007) has reported that control was performed to verify the antimicrobial potential of detergents assayed such as Tween-80, Triton X-100, SDS and urea at $1 \%$ of concentration, and none demonstrated antimicrobial activity per se.

Lactobacillus brevis C23 was able to survive and grow at $0.3 \%, 0.5 \%$ and $1 \%$ of bile salts for $5 \mathrm{~h}$. In the study by Gilliland et al. (1984), $0.3 \%$ of bile salts are considered as a threshold concentration for screening of bile salts resistant strains. The methods of determination of resistant strains (delay of growth, $\mathrm{d} \leq 15 \mathrm{~min}$ ), tolerant strains (15 min $<d \leq 40 \mathrm{~min}$ ), weakly tolerant strains (40 $\min <\mathrm{d}<60 \mathrm{~min}$ ) and sensitive strains ( $\leq 60 \mathrm{~min}$ ) were used. In this study, L. brevis C23 at $0.3 \%, 0.5 \%$ and $1 \%$ of bile salts was able to grow parallel to the control strain up to $4 \mathrm{~h}$, indicating that the L. brevis C23 is highly tolerant to bile salts. Similar studies showed that Pediococcus pentosaceus CE65 able to survive at $0.3 \%$ bile salts (Manini et al., 2016). Another study with $L$. mucosae AN1 also showed resistance towards bile salts from 0.1 to $0.7 \%$ (Repally et al., 2018).

For the adsorption study, the antimicrobial activity of CFS (pH 2) after the cell washing had almost no activity indicating that all the antimicrobial peptides did not adhere to the surface of the producer cells (Banerjee et al., 2013). Similar studies were observed for pediocin ST18, brevicin FPTLB3, and plantaricin C19 where no antimicrobial activity was recoded at $\mathrm{pH} 2$ suggesting the bacteriocin did not adhere on the producer cells (Atrih et al., 2001; Todorov and Dicks, 2005; Banerjee et al., 2013).

Listeria monocytogenes ATCC 7644 when treated with CFS, the cell wall and cytoplasm membrane were disintegrated and spewing the cytoplasmic content out. This shows the CFS from L. brevis C23 facilitated the cell wall and cytoplasm permeability thus reducing the integrity of the membrane resulting the dispersion of the cytoplasmic content and cell death (Qiao et al., 2020). Similar results was reported on the Bacillus cereus when treated with bacteriocin from Weissella confusa $A 3$ and $L$. monocytogenes CMCC 1595 when treated with enterocin TJUQ1 (Goh and Philip, 2015; Qiao et al., 2020).

\section{CONCLUSION}

Lactobacillus brevis C23 isolated from cabbage had shown a very high potential in food preservation or usage as coating for food packaging application. The CFS showed a significantly high antimicrobial activity against food pathogen, $L$. monocytogenes ATCC 7644 . The BLIS of $L$. brevis C23 was proteinaceous nature. The CFS of $L$. brevis C23 did not favour alkaline environment but showed high antimicrobial activity at acidic environment. Hence, the CFS able to withstand at lower $\mathrm{pH}$ and is useful in packaging or preserving acidic and pickled foods. In addition, the CFS was not affected by detergents which play an important role in food industry. Moreover, the CFS able to withstand bile salts even at critical concentration. Combining with the survivability at low $\mathrm{pH}$ and critical bile salts concentration, the CFS able to withstand the digestive environment in our body. The antimicrobial activity of CFS was elucidated as the cell 
lysis was occurred to the L. monocytogenes. However, additional studies are required to verify in vivo the effectiveness of selected strains and analyse the components that are present in the CFS using SDSPAGE method.

\section{ACCESSION NUMBER}

Lactobacillus brevis strain C23 16S ribosomal RNA gene, partial sequence, MN880215.

\section{ACKNOWLEDGEMENTS}

Authors acknowledge the financial supports received by Ministry of Higher Education (MOHE), Malaysia under Fundamental Research Grant Scheme (203/PTENKIND/6711624).

\section{REFERENCES}

Abbasiliasi, S., Tan, J. S., Bashokouh, F., Ibrahim, T. A. T., Mustafa, S., Vakhshiteh, F., Sivasamboo, S. and Ariff, A. B. (2017). In vitro assessment of Pediococcus acidilactici Kp10 for its potential use in the food industry. BMC Microbiology 17(1), 1-11.

Abbasiliasi, S., Tan, J. S., Ibrahim, T. A. T., Ramanan, R. N., Vakhshiteh, F., Mustafa, S., Ling, T. C., Rahim, R. A. and Ariff, A. B. (2012). Isolation of Pediococcus acidilactici Kp10 with ability to secrete bacteriocin-like inhibitory substance from milk products for applications in food industry. BMC Microbiology 12(1), 1-12.

Abdulmumeen, H. A., Risikat, A. N. and Sururah, A. R. (2012). Food: Its preservatives, additives and applications. International Journal of Chemical and Biochemical Sciences 1, 36-47.

Albano, H., Todorov, S. D., van Reenen, C. A., Hogg, T., Dicks, L. M. and Teixeira, P. (2007). Characterization of two bacteriocins produced by Pediococcus acidilactici isolated from "Alheira", a fermented sausage traditionally produced in Portugal. International Journal of Food Microbiology 116(2), 239-247.

Amézquita, A. and Brashears, M. M. (2002). Competitive inhibition of Listeria monocytogenes in ready-to-eat meat products by lactic acid bacteria. Journal of Food Protection 65(2), 316-325.

Atrih, A., Rekhif, N., Moir, A. J. G., Lebrihi, A. and Lefebvre, G. (2001). Mode of action, purification and amino acid sequence of plantaricin C19, an antiListeria bacteriocin produced by Lactobacillus plantarum C19. International Journal of Food Microbiology 68(1-2), 93-104.

Avaiyarasi, N. D., Ravindran, A. D., Venkatesh, P. and Arul, V. (2016). In vitro selection, characterization and cytotoxic effect of bacteriocin of Lactobacillus sakei GM3 isolated from goat milk. Food Control 69, 124133.

Banerjee, S. P., Dora, K. C. and Chowdhury, S. (2013). Detection, partial purification and characterization of bacteriocin produced by Lactobacillus brevis FPTLB3 isolated from freshwater fish. Journal of Food Science and Technology 50(1), 17-25.

Choi, S. H. and Chin, K. B. (2003). Evaluation of sodium lactate as a replacement for conventional chemical preservatives in comminuted sausages inoculated with Listeria monocytogenes. Meat Science 65(1), 531-537.

Gilliland, S. E., Staley, T. E. and Bush, L. J. (1984). Importance of bile tolerance of Lactobacillus acidophilus used as a dietary adjunct. Journal of Dairy Science 67(12), 3045-3051.

Goh, H. F. and Philip, K. (2015). Purification and characterization of bacteriocin produced by Weissella confusa A3 of dairy origin. PLOS ONE 10(10), e0140434.

Güllüce, M., Karadayı, M., and Barış, Ö. (2013). Bacteriocins: Promising natural antimicrobials. In: Microbial Pathogens and Strategies for Combating Them: Science, Technology and Education. MéndezVilas, A. (ed.). FORMATEX, Madrid, Spain. pp. 10161027.

Ivanova, I., Miteva, V., Stefanova, T. S., Pantev, A., Budakov, I., Danova, S., Moncheva, P., Nikolova, I., Dousset, X. and Boyaval, P. (1998). Characterization of a bacteriocin produced by Streptococcus thermophilus 81. International Journal of Food Microbiology 42(3), 147-158.

Manini, F., Casiraghi, M. C., Poutanen, K., Brasca, M., Erba, D. and Plumed-Ferrer, C. (2016). Characterization of lactic acid bacteria isolated from wheat bran sourdough. LWT - Food Science and Technology 66, 275-283.

Millette, M., Dupont, C., Archambault, D. and Lacroix, M. (2007). Partial characterization of bacteriocins produced by human Lactococcus lactis and Pediococccus acidilactici isolates. Journal of Applied Microbiology 102(1), 274-282.

Nettles, C. G. and Barefoot, S. F. (1993). Biochemical and genetic characteristics of bacteriocins of foodassociated lactic acid bacteria. Journal of Food Protection 56(4), 338-356.

Ng, Z. J., Zarin, M. A., Lee, C. K., Phapugrangkul, P. and Tan, J. S. (2020). Isolation and characterization of Enterococcus faecium DSM 20477 with ability to secrete antimicrobial substance for the inhibition of oral pathogen Streptococcus mutans UKMCC 1019. Archives of Oral Biology 110, 104617.

Ogunbanwo, S. T., Sanni, A. I. and Onilude, A. A. (2003). Characterization of bacteriocin produced by Lactobacillus plantarum F1 and Lactobacillus brevis OG1. African Journal of Biotechnology 2(8), 219-227.

Qiao, X., Du, R., Wang, Y., Han, Y. and Zhou, Z. (2020). Purification, characterization and mode of action of enterocin, a novel bacteriocin produced by Enterococcus faecium TJUQ1. International Journal of Biological Macromolecules 144, 151-159.

Repally, A., Perumal, V., Dasari, A., Palanichamy, E. and Venkatesan, A. (2018). Isolation, identification of Lactobacillus mucosae AN1 and its antilisterial peptide 
purification and characterization. Probiotics and Antimicrobial Proteins 10(4), 775-786.

Riaz, A., Noureen, S., Liqat, I., Arshad, M. and Arshad, N. (2019). Antilisterial efficacy of Lactobacillus brevis MF179529 from cow: An in vivo evidence. BMC Complementary and Alternative Medicine 19(1), 1-9.

Shamloo, E., Hosseini, H., Abdi Moghadam, Z., Halberg Larsen, M., Haslberger, A. and Alebouyeh, M. (2019). Importance of Listeria monocytogenes in food safety: A review of its prevalence, detection, and antibiotic resistance. Iranian Journal of Veterinary Research 20(4), 241.

Složilová, I., Purkrtova, S., Kosova, M., MIhULOVÁ, M., Šviráková, E. and Demnerová, K. (2014). Antilisterial activity of lactic acid bacteria against Listeria monocytogenes strains originating from different sources. Czech Journal of Food Sciences 32(2), 145-151.

Todorov, S. D. and Dicks, L. M. T. (2005). Pediocin ST18, an anti-listerial bacteriocin produced by Pediococcus pentosaceus ST18 isolated from boza, a traditional cereal beverage from Bulgaria. Process Biochemistry 40(1), 365-370.

Todorov, S. D., Ho, P., Vaz-Velho, M. and Dicks, L. M. T. (2010). Characterization of bacteriocins produced by two strains of Lactobacillus plantarum isolated from Beloura and Chouriço, traditional pork products from Portugal. Meat Science 84(3), 334-343.

Ünlü, G., Nielsen, B. and Ionita, C. (2016). Inhibition of Listeria monocytogenes in hot dogs by surface application of freeze-dried bacteriocin-containing powders from lactic acid bacteria. Probiotics and Antimicrobial Proteins 8(2), 102-110.

Vaughan, E. E., Daly, C. and Fitzgerald, G. F. (1992). Identification and characterization of helveticin $\mathrm{V}$ 1829, a bacteriocin produced by Lactobacillus helveticus 1829. Journal of Applied Bacteriology 73(4), 299-308.

Wang, Y., Qin, Y., Xie, Q., Zhang, Y., Hu, J. and Li, P. (2018). Purification and characterization of plantaricin LPL-1, a novel class Ila bacteriocin produced by Lactobacillus plantarum LPL-1 isolated from fermented fish. Frontiers in Microbiology 9, 2276.

Yang, R., Johnson, M. C. and Ray, B. (1992). Novel method to extract large amounts of bacteriocins from lactic acid bacteria. Applied and Environmental Microbiology 58(10), 3355-3359.

Yi, L., Dang, J., Zhang, L., Wu, Y., Liu, B. and Lü, X. (2016). Purification, characterization and bactericidal mechanism of a broad spectrum bacteriocin with antimicrobial activity against multidrug-resistant strains produced by Lactobacillus coryniformis XN8. Food Control 67, 53-62. 